\title{
About the editor
}

Yipeng Liu is Professor in Management and Organization Studies at Henley Business School, University of Reading, UK. Professor Liu obtained a Doctorate in Management (magna cum laude) from Mannheim University, Germany. He is a faculty member at the European Institute for Advanced Studies in Management (EIASM), Belgium; Fellow of the Higher Education Academy, UK; Visiting Professor at Aarhus University, Denmark; Alcoa Visiting Professor at University of Western Australia Business School, Australia; Schöller Fellow at Dr. Theo and Friedl Schöller Research Center for Business and Society, Germany; Director at the Center for China and Globalization UK Chapter (London), and Research Fellow at the Institute for SME Research, Mannheim, Germany. He has been a visiting scholar at Columbia University in New York City, Florida International University in Miami, and the China Europe International Business School in Shanghai. His research has been sponsored by the Leverhulme Trust, British Academy, the Sino-British Fellowship Trust, the German Academic Exchange Service (DAAD) in Germany, and others.

His research areas include entrepreneurship and innovation, mergers and acquisitions, talent mobility and entrepreneurship ecosystems, and business sustainability. His work is published in leading academic journals, such as Human Resource Management, British Journal of Management, Journal of World Business, Regional Studies, Technovation, International Business Review, among others. He has served as a guest editor for special issues of several leading management and organization journals. He currently serves as Senior Editor for Management and Organization Review and Associate Editor for Asian Business \& Management. 